\title{
MODEL PEMILIHAN VENDOR TRUCKING PRIORITAS DAN ALOKASI ORDER UNTUK DELIVERY PROJECT ACCOUNT PERFETTI VAN MELLE INDONESIA (CASE STUDY : PT DAMCO INDONESIA)
}

\author{
Erna Mulyati, Made Prima Widyapurna \\ Politeknik Pos Indonesia, Jl. Terusan Sari Asih No. 54 Bandung 40151 - Indonesia \\ rna_rian@yahoo.com
}

\begin{abstract}
Abstrak
Proses pemilihan vendor sangat penting untuk diperhatikan dan dilaksanakan sebaik mungkin dalam upaya memberikan dan meningkatkan pelayanan yang diberikan demi terciptanya kepuasan pelanggan secara maksimal. PT Damco Indonesia harus mampu menentukan dan memilih mitra kerja terbaik yang memiliki kualitas kinerja sesuai dengan standar yang telah ditetapkan perusahaan, khususnya dalam memilih vendor. Kesalahan memilih Vendor dapat menyebabkan kerugian bagi perusahaan. Fuzzy Synthetic Evaluation merupakan suatu metode yang digunakan untuk menilai kinerja vendor yang memberi fleksibilitas untuk menampung ketidakpastian akibat samarnya informasi yang dimiliki maupun unsur preferensi yang subjektif yang dapat digunakan dalam masalah pengambilan keputusan. Metode ini digunakan untuk mendapatkan Third Party Logistic (3PL) yang akan digunakan untuk mengalokasikan order ke pelanggan. Pengalokasi order dilakukan dengan mengaplikasikan algoritma transportasi. Penulis menggunakan dua buah metode dalam algoritma ini yaitu Vogell's Aproximation Method (VAM) untuk penentuan tabel awalnya dan Modified Distribution Method untuk melakukan pengujian terhadap tabel awal yang terbentuk untuk melihat keoptimalannya. Hasil urutan kriteria performansi berdasarkan kuesioner pembobotan yang telah ditentukan melalui tahapan wawancara dan studi lapangan di perusahaan yaitu harga/tarif, network coverage, office equipment, infratruktur dan kualitas pelayanan, dimana terdapat sub kriteria untuk kualitas yang terdiri dari kualitas alat angkut beserta umur peralatan, asuransi, dan ability to provide Custome Delivery. Hasil perhitungan dengan Fuzzy Synthetic Evaluation diperoleh hasil vendor PT Adi Sarana Armada dan Muna Jaya Expres sama-sama memiliki nilai keanggotaan terbesar yaitu 0,22 di kategori "baik" yang berarti bahwa kedua vendor tersebut memiliki kinerja yang lebih baik dibandingkan dengan vendor trucking lainnya. Metode Vogell's Aproximation Method (VAM) dan Modified Distribution Method yang digunakan untuk pengalokasiannya menghasilkan biaya distribusi yang telah optimal dengan total biaya Rp8.467.347, di mana PT Adi Sarana Armada terpilih sebagai vendor prioritas untuk wilayah kiriman Banten, Lampung, dan Tanggerang, sementara Muna Jaya Express terpilih sebagai vendor prioritas untuk wilayah kiriman Surabaya, Malang, dan Jember.
\end{abstract}

Kata Kunci : vendor, trucking, fuzzy synthetic evaluation, vogell's aproximation method, modified distribution method

\begin{abstract}
Vendor selection process is very important to be considered and implemented as possible in an effort to provide and improve services provided for the creation of customer satisfaction to the fullest. Damco PT Indonesia must be able to pick and choose the best partner that has the quality of performance in accordance with standards set by the company, particularly in choosing a vendor. Vendors may choose errors cause harm to the company, so it is necessary to assess the performance of trucking vendors who have been cooperating with Damco PT Indonesia, so the company can continue to maintain the quality of service. Fuzzy Synthetic Evaluation is a method used to assess the performance of vendors provide flexibility to accommodate the uncertainty due to information held vague and subjective elements of the preferences that can be used in decision-making problems. This method is expected to be able to effectively and efficiently enable the company to be able to take the best decision in selecting a vendor trucking so that earned Third Party Logistic (3PL) that will be used to allocate the order to the customer. Order allocator is done by applying the transport algorithm. The author uses two methods in this algorithm is Vogell's Aproximation Method (VAM) for determining the initial table and Modified Distribution Method for a test of the initial table is created to look optimalization. This method was
\end{abstract}


chosen because it is relatively easy to be applied to companies in which to work on the calculations can be completed with excel solver which is now owned by perusaaan. The results of the performance criteria based on questionnaires sequence weighting has been determined through interviews and field work phases of the company ie prices / tariffs, network coverage, office equipment, infrastructure and quality of service, where there are sub criteria for quality of life and its quality of conveyance equipment, insurance, and the ability to provide custome delivery. The results of calculations with Fuzzy Synthetic Evaluation obtained the vendor PT Adi Sarana Armada and Muna Jaya Expres both have the largest membership value is 0.22 in the category of "good" meaning that the vendor has better performance compared with other trucking vendors. Aproximation Vogell's method Method (VAM) and Modified Distribution Method used to generate allocation of distribution costs that have been optimized with a total cost of Rp8.467.347, where PT Adi Sarana Armada vendor was selected as a priority for the shipment Banten, Lampung, and Tangerang, while Muna Jaya Express was selected as a priority for the vendor submissions Surabaya, Malang, and Jember. These priorities are determined from the price of items supplied by each vendor for each shipment destination.

Keywords : vendor, trucking, fuzzy synthetic evaluation, vogell's aproximation method, modified distribution method

\section{PENDAHULUAN}

Segmen transportasi merupakan kontributor terbesar dalam biaya logistik yang diikuti oleh freight forwarding dan pergudangan. Biaya logistik merupakan faktor penting yang digunakan dalam pemilihan Third Party Logistic (3PL). Penggunaan Third Party Logistic (3PL) selama ini telah mengurangi biaya logistik perusahaan, sehingga banyak perusahaan yang menggunakan jasa Third Party Logistic (Frost dan Sullivan, 2007). Menurut Frost dan Sullivan, (2007), biaya logistik di Indonesia sangat tinggi (19.5\%) dibandingkan dengan negara ASEAN yang lainnya, seperti Malaysia (12.5\%) dan Singapura sebesar $8.1 \%$.

Penelitian ini menggunakan metode Fuzzy Synthetic Evaluation. Metode ini digunakan dengan pertimbangan bahwa dalam usaha pengambilan keputusan banyak sekali dijumpai variabel-variabel linguistic. Variabel linguistic adalah variabel-variabel yang mengandung ketidakpastian sehingga operasi-operasi klasik (contohnya: Boolean, Aristotelian logic) bisa jadi akan menghasilkan kesimpulan yang salah, karena mereka hanya mengenal benar dan salah atau 0 dan 1. Pengalokasian order dilakukan dengan menggunakan dua buah metode algoritma yaitu Vogell's Aproximation Method (VAM) untuk penentuan tabel awalnya dan Modified Distribution Method untuk melakukan pengujian terhadap tabel awal yang terbentuk untuk melihat keoptimalannya. Metode ini dipilih karena relatif cukup mudah untuk dapat diaplikasikan ke perusahaan dimana untuk pengerjaan perhitungannya dapat diselesaikan dengan solver excel yang mana saat ini sudah dimiliki oleh perusaaan. Penelitian ini dilakukan dengan alasan ditemukannya penurunan Casefill Performanse untuk total kiriman dari bulan Maret (turun sampai dengan 3\%) hingga bulan Mei, serta belum ditentukannya metode pengalokasian order untuk masingmasing vendor terpilih. Sedangkan tujuan penelitian ini adalah untuk menghasilkan metode pengukuran kinerja yang dapat membantu perusahan untuk penentuan vendor prioritas serta alokasi ordernya.

\section{METODE YANG DIGUNAKAN Fuzzy synthetic evaluation}

Fuzzy synthetic evaluation digunakan untuk dapat menilai kinerja dari alternatif atau mitra kerja yang ada. Sifat synthetic (buatan) yang terdapat pada metode pengambilan keputusan ini merujuk kepada proses evaluasi dimana beberapa komponen dan unsur-unsur individu dari suatu evaluasi disatukan ke dalam suatu kumpulan dari keseluruhan adalah suatu bagian, dengan demikian kriteria penilaian kinerja dapat ditentukan sesuai dengan kebutuhan dari pihak-pihak yang menggunakannya. Terdapat beberapa tahapan dalam pengelolaan data dengan metode ini, yaitu:

1. Perumusan Kuesioner 1 dan Penetapan Responden 
Tujuan dibuatnya perumusan ini adalah untuk mengetahui penilaian responden dalam melakukan penilaian terhadap kualitas kinerja vendor yang selama ini telah menjalin kerjasama dengan perusahaan.

2. Perumusan Kuesioner 2 dan Penetapan Responden

Tujuan dibuatnya perumusan ini adalah untuk mendapatkan fungsi keanggotaan (membership function).

3. Penyebaran Kuesioner dan Pengumpulan Nilai Matriks melalui Lembar Penilaian.

Penyebaran kuesioner yang ditujukan kepada orang-orang yang ahli dibidangnya

4. Membuat Tabulasi dan Matriks dari Hasil Kuesioner 1 (Matriks W)

Hasil kuesioner 1 dengan jawaban 5 orang responden diolah menjadi satu, kemudian hasil tersebut dimasukkan ke dalam sebuah Tabel. Berdasarkan hasil tabulasi dari tabel sebelumnya, maka diolah lagi menjadi 5 matriks. Dan kemudian hasilnya disatukan menjadi sebuah matrik dengan rumus :

$\mathrm{A}=\mathrm{A} 1+\mathrm{A} 2+\mathrm{A} 3+\mathrm{A} 4+\mathrm{A} 5$

dimana A merupakan hasil perhitungan untuk masing-masing responden.

5. Berdasarkan penjumlahan matrik tadi kemudian dibuat plot berupa grafik per kategori dari respon kualitatif (kuisioner 2), adapun kategorinya adalah SBR (Sangat Buruk), BR (Buruk), C (Cukup), BK (Baik), SBK (Sangat baik).

6. Menentukan Fungsi keanggotaan (membership function)

Fungsi keanggotaan kurva sangat buruk menggunakan regresi sederhana atau Approaximasi Linier dengan rumus sebagai berikut:

$$
\overline{\boldsymbol{Y}}_{\boldsymbol{i}}=\hat{\boldsymbol{\beta}}_{1}+\hat{\boldsymbol{\beta}}_{\mathbf{2}}^{*} \overline{\boldsymbol{X}}_{\boldsymbol{i}}
$$

Sementara untuk kategori kurva buruk, cukup dan baik, Penulis menggunakan pendekatan kurva beta (Lonceng), dimana fungsi keanggotaannya ditentukan dengan rumus:

$$
B(x ; \gamma, \beta)=\frac{1}{1+\left(\frac{x-\gamma}{\beta}\right)^{2}}
$$

dimana penyelesaiannya penulis dibantu dengan software Matchad 15.0, dan untuk kurva sangat baik penulis menggunakan persamaan:

$\mathrm{y}=\mathrm{mx}+\mathrm{c}$

7. Membuat Matriks $R$

Untuk membuat matriks $\mathrm{R}$, digunakan hasil kuesioner 1 dari masing-masing vendor berdasarkan masing-masing kriteria, untuk kriteria yang memiliki sub kriteria digunakan rumus:

$\left(\mathrm{Z}_{1} \times\right.$ Sub weight $\left.{ }_{1}\right)+\left(\mathrm{Z}_{2} \times\right.$ Sub weight $\left.{ }_{2}\right)$, $\ldots,\left(Z_{n} \times\right.$ Sub weight $\left.{ }_{n}\right) \ldots \ldots .(5)$

di mana $\mathbf{Z}_{\mathbf{1}}, \mathbf{Z}_{\mathbf{2}}, \mathbf{Z}_{\mathbf{n}}=$ hasil dari sub kriteria, kuesioner 1 yang telah diolah, dan Sub weight, ${ }_{1}$, Sub weight ${ }_{2}$, Sub weight $_{\mathbf{n}}=$ bobot dari sub kriteria

8. Mengkomposisikan Matrik W dan Matrik $\mathrm{R}$

Mengkomposisikan matriks W, dengan setiap kategori dari seluruh kriteria yang ada, yaitu dengan cara ambil dulu yang minimal dari setiap kategori, kemudian setelah ke-lima kategori tersebut dikomposisikan diambil yang maksimal dan dimasukkan kedalam matriks e.

MAX-MIN : $\mu_{B^{\prime}}(\mathrm{Y})=\underset{i=1}{M A} X\left[\operatorname{supmin}\left(\mu_{A^{\prime}}(X), \mu_{A i t}\left(x_{i}\right) \ldots \ldots . ., \mu_{A n}\left(x_{n}\right) \mu_{B^{\prime}}(Y)\right)\right]$

\section{Vogell Approximation Method (VAM) / Matriks Transportasi}

Metode Pendekatan Vogel

diperkenalkan oleh WR. Vogel tahun 1948. Vogel Approximation Method (VAM) adalah metode untuk penentuan tabel awal algoritma transportasi. Prinsip dari metode ini adalah memilih harga-harga ongkos terkecil tiap-tiap baris kemudian menghitung selisih antara ongkos terkecil tersebut dengan ongkos terkecil berikutnya. Selisihnya nol tidak diperhatikan dalam hal ini. Hal yang sama diperlakukan terhadap kolom. Bilangan-bilangan selisih tersebut dikenal dengan bilangan Vogel. Sebuah matriks transportasi memiliki $\mathrm{m}$ baris dan n kolom. Sumber-sumber berjajar pada baris ke-1 hingga ke-m, sedangkan 
tujuan-tujuan berjajar dari kolom ke-1 hingga ke-n, dengan demikian,

$\mathrm{X}_{\mathrm{ij}}$ : satuan barang yang akan diangkut dari sumber $\mathrm{i}$ ke tujuan $\mathrm{j}$

$\mathrm{b}_{\mathrm{ij}}$ : biaya angkut per satuan barag dari sumber $\mathrm{i}$ ke tujuan $\mathrm{j}$, sehingga secara matematis:

$\operatorname{Min} \sum_{i=1}^{m} \sum_{j=1}^{n} b_{i j} X_{i j}$

\section{Modified distribution Method}

MODI menguji optimalitas tabel dari matriks yang dibentuk dari metode Vogell Approximation Method dengan cara menghitung opportunity cost pada sel-sel yang tidak terkena alokasi distribusi. Suatu tabel dikatakan optimal bila dan hanya bila opportunity cost $\left(\mathrm{O}_{\mathrm{ij}}\right)$ sel-sel kosong adalah negatif atau nol, di mana untuk seluruh sel berlaku persamaan:

$\mathrm{O}_{\mathrm{ij}}=\left(\mathrm{U}_{\mathrm{i}}+\mathrm{V}_{\mathrm{j}}\right)-\mathrm{C}_{\mathrm{ij}}$

dimana,

$\mathrm{U}_{\mathrm{i}}$ : Angka kunci pada setiap baris $\mathrm{i}$

$\mathrm{V}_{\mathrm{j}}$ : Angka kuci pada setiap kolom $\mathrm{j}$

$\mathrm{C}_{\mathrm{ij}}$ : Biaya distribusi yang nyata pada sel $\mathrm{ij}$

$\mathrm{O}_{\mathrm{ij}}$ : Opportunity Cost pada sel ij

Bila dijumpai paling sedikit satu sel kosong yang memiliki opportunity cost positif atau $\mathrm{O}_{\mathrm{ij}}>0$ maka dikatakan bahwa tabel belum optimal sehingga harus direvisi.

\section{HASIL PENELITIAN PEMBAHASAN}

Kriteria pengukuran kinerja yang

DAN gunakan dalam penelitian ini terdiri dari harga/tarif, network coverage, office equipment, infratruktur dan kualitas pelayanan, dimana terdapat sub kriteria untuk kualitas yang terdiri dari kualitas alat angkut beserta umur peralatan, asuransi, dan ability to provide Custome Delivery. Bilangan linguistic fuzzy number yang digunakan dalam penelitian ini adalah 0,0 ; 0,$1 ; 0,2 ; 0,3 ; 0,4 ; 0,5 ; 0,6 ; 0,7 ; 0,8 ; 09 ; 1,0$.

Dari penilaian bilangan linguistic fuzzy number yang diberikan para pakar dengan menggunakan rumus [1] diperoleh hasil seperti yang ditunjukkan Tabel1.

Rumus 2 selanjutnya digunakan untuk menentukan membership funtion untuk kurva sangat baik. Membership function untuk Kurva Buruk, Cukup, serta Kurva baik diselesaikan dengan menggunakan persamaan [3], dimana untuk turunan terhadap $\alpha$ diperoleh:

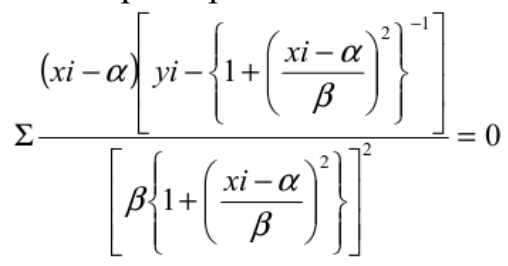

sedangkan turunan terhadap $\beta$ diperoleh persamaan:

$$
\sum \frac{\left[y i-\left\{1+\left(\frac{x i-\alpha}{\beta}\right)^{2}\right\}^{-1}\right]\left(\frac{x i-\alpha}{\beta}\right)^{2}}{\beta\left[1+\left(\frac{x i-\alpha}{\beta}\right)^{2}\right]^{2}}=0
$$

Tabel 1 Tabel Ploting untuk Membuat Grafik

\begin{tabular}{ccccccccccc}
\hline & \multirow{2}{*}{$\mathrm{SBR}$} & \multirow{2}{*}{$\mathrm{BR}$} & $\mathrm{C}$ & $\mathrm{BK}$ & $\mathrm{SBK}$ & $\mathrm{SBR} /$ & $\mathrm{BR} /$ & $\mathrm{C} /$ & $\mathrm{BK} /$ & $\mathrm{SBK} /$ \\
& & & & & & $\Sigma$ & $\Sigma$ & $\Sigma$ & $\Sigma$ \\
\hline 0 & 25 & 0 & 0 & 0 & 0 & 0,44 & 0,00 & 0,00 & 0,00 & 0,00 \\
0,1 & 23 & 2 & 0 & 0 & 0 & 0,40 & 0,04 & 0,00 & 0,00 & 0,00 \\
0,2 & 9 & 16 & 0 & 0 & 0 & 0,16 & 0,30 & 0,00 & 0,00 & 0,00 \\
0,3 & 0 & 25 & 0 & 0 & 0 & 0,00 & 0,46 & 0,00 & 0,00 & 0,00 \\
0,4 & 0 & 11 & 14 & 0 & 0 & 0,00 & 0,20 & 0,23 & 0,00 & 0,00 \\
0,5 & 0 & 0 & 25 & 0 & 0 & 0,00 & 0,00 & 0,40 & 0,00 & 0,00 \\
0,6 & 0 & 0 & 22 & 3 & 0 & 0,00 & 0,00 & 0,35 & 0,06 & 0,00 \\
0,7 & 0 & 0 & 1 & 24 & 0 & 0,00 & 0,00 & 0,02 & 0,48 & 0,00 \\
0,8 & 0 & 0 & 0 & 21 & 4 & 0,00 & 0,00 & 0,00 & 0,42 & 0,08 \\
0,9 & 0 & 0 & 0 & 2 & 23 & 0,00 & 0,00 & 0,00 & 0,04 & 0,44 \\
1 & 0 & 0 & 0 & 0 & 25 & 0,00 & 0,00 & 0,00 & 0,00 & 0,48 \\
\hline$\Sigma$ & $\mathbf{5 7}$ & $\mathbf{5 4}$ & $\mathbf{6 2}$ & $\mathbf{5 0}$ & $\mathbf{5 2}$ & & & & & \\
\hline
\end{tabular}


Memberhip function diperoleh dengan bantuan software Matchad 15.0 dengan memasukkan nilai kedekatan terhadap bilangan linguistic fuzzy number yang ditunjukkan pada tabel 1 untuk masingmasing kategori. Sementara untuk kurva sangat baik membership function-nya ditemukan dengan persamaan [4] dan persamaan:

$\sum \varepsilon_{i}^{2}=\Sigma\left(Y_{i}-Y_{i}\right)^{2}$.

Persamaan-persamaan tersebut di atas akan menjadi fungsi keanggotaan setelah persamaannya didapatkan sesuai dengan kategorinya, adapun fungsi keanggotaannya adalah sebagai berikut:

1. Sangat Buruk (SBR)

$$
\begin{aligned}
& \mu_{\mathrm{SBR}}(\mathrm{X})=0,48-1,56 \mathrm{X} \ldots \ldots \ldots \ldots \ldots \ldots . . .(7) \\
& \mu_{S B R}(X)=\left\{\begin{array}{c}
0,48-1,56 X ; X<0,31 \\
0 ; X \geq 0,31
\end{array}\right.
\end{aligned}
$$

2. Buruk (BR)

$$
\mu_{B R}(X)=\frac{1}{1+\left(\frac{x-0,8}{0,06}\right)^{2}} .
$$

3. Cukup (C)

$$
\mu_{C}(X)=\frac{1}{1+\left(\frac{x-0,5}{0,06}\right)^{2}} .
$$

4. Baik (BK)

$$
\mu_{B K}(X)=\frac{1}{1+\left(\frac{x-0, z}{0,05}\right)^{2}}
$$

5. Sangat Baik (SBK)

$$
\begin{gathered}
\mu_{\mathrm{SBK}}(\mathbf{X})=1,63 X-1,15 \ldots \ldots \ldots \ldots . \\
\mu_{S B K}(X)=\left\{\begin{array}{c}
1,63 X-1,15 ; X \geq 0,71 \\
0 ; X<0,71
\end{array}\right.
\end{gathered}
$$

\begin{tabular}{|c|c|c|c|c|c|}
\hline $\begin{array}{c}\text { Resp } \\
\text { on }\end{array}$ & $\begin{array}{c}\text { Har } \\
\text { ga }\end{array}$ & $\begin{array}{c}\text { netw } \\
\text { ork } \\
\text { cover } \\
\text { age }\end{array}$ & $\begin{array}{l}\mathrm{O} \\
\mathrm{E}\end{array}$ & $\begin{array}{c}\mathrm{IN} \\
\mathrm{F}\end{array}$ & $\begin{array}{l}\mathrm{S} \\
\mathrm{Q}\end{array}$ \\
\hline 1 & $\begin{array}{c}0,9 \\
5\end{array}$ & 1 & $\begin{array}{c}0, \\
76\end{array}$ & $\begin{array}{l}0 \\
8\end{array}$ & $\begin{array}{c}0, \\
82\end{array}$ \\
\hline 2 & $\begin{array}{c}0,9 \\
7\end{array}$ & 0,97 & $\begin{array}{l}0 \\
8\end{array}$ & $\begin{array}{c}0, \\
95\end{array}$ & $\begin{array}{c}0, \\
76\end{array}$ \\
\hline 3 & 1 & 0,9 & $\begin{array}{l}0, \\
6\end{array}$ & $\begin{array}{c}0 \\
9\end{array}$ & 1 \\
\hline 4 & 1 & 0,9 & 1 & $\begin{array}{c}0, \\
98\end{array}$ & 1 \\
\hline 5 & 1 & 0,93 & $\begin{array}{l}0 \\
95\end{array}$ & 1 & $\begin{array}{c}0, \\
85\end{array}$ \\
\hline
\end{tabular}

\section{Membuat Matriks W}

\begin{tabular}{|c|c|c|c|c|c|c|c|}
\hline$\Sigma$ & $\begin{array}{c}4,9 \\
2\end{array}$ & 4,7 & $\begin{array}{l}4, \\
11\end{array}$ & $\begin{array}{l}4, \\
63\end{array}$ & $\begin{array}{l}4, \\
43\end{array}$ & & \\
\hline$\Sigma / 5$ & $\begin{array}{c}0,9 \\
8\end{array}$ & 0,94 & $\begin{array}{c}0, \\
82\end{array}$ & $\begin{array}{c}0, \\
93\end{array}$ & $\begin{array}{c}0, \\
89\end{array}$ & $\Sigma$ & $\begin{array}{c}4,5 \\
58\end{array}$ \\
\hline$\%$ & $\begin{array}{c}0,2 \\
2 \\
\end{array}$ & 0,21 & $\begin{array}{c}0, \\
18 \\
\end{array}$ & $\begin{array}{l}0, \\
20 \\
\end{array}$ & $\begin{array}{c}0, \\
19 \\
\end{array}$ & & \\
\hline & 22 & 21 & 18 & 20 & 19 & & \\
\hline
\end{tabular}

Matrik W diperoleh dari hasil penilaian para pakar dalam kuisioner 1, yang mana matriks ini adalah bobot untuk masing-masing kriteria.

Tabel 2 Tabel Nilai Bobot Kriteria
Tabel 3 Tabel Nilai Bobot sub kriteria dari 5 responden

\begin{tabular}{cccccc}
\hline \multirow{2}{*}{ Respon } & \multirow{2}{*}{ Umur } & $\begin{array}{c}\text { Jaminan } \\
\text { Asuransi }\end{array}$ & $\begin{array}{c}\text { Custome } \\
\text { Delivery }\end{array}$ & \\
\hline$\square$ & 4,51 & 4,8 & 4,35 & & \\
$\square \square \square$ & 0,902 & 0,96 & 0,87 & 2,732 \\
$\%$ & 0,33 & 0,35 & 0,32 & & \\
\hline & 33 & 35 & 32 & & \\
\hline
\end{tabular}

Setelah kita mendapatkan nilai untuk kriteria kualitas maka langkah selanjutnya yaitu kita membuat matriks $\mathrm{R}$ per masing-masing vendor. Nilai-nilai ini didapatkan dengan memasukan angkaangka pada persamaan sebelumnya, yaitu persamaan [7] untuk SBR, persamaan [8] untuk BR, persamaan [9] untuk $C$, persamaan [10] untuk BK, persamaan [11] untuk SBK.

\section{Mengkomposisikan matriks $\mathbf{W}$ dan $R$ $\left(\mathbf{W}^{\circ} \mathbf{R}\right)$}

Cara mengkomposisikan matriks W dengan matriks $\mathrm{R}$ adalah, dengan cara matriks W dibandingkan dengan kolom matriks per kategori SBR, BR, C, BK, SBK. Caranya,nilai yang ada pada matriks W dibandingkan dengan kolom matriks SBR, ambil nilai yang minimal, matriks W dibandingkan dengan kolom matriks BR, ambil nilai yang minimal, dan seterusnya sampai matrik SBK. Setelah semua matriks kategori (R) dibandingkan dengan matriks $\mathrm{W}$, dari setiap hasil tadi ambil yang maximal untuk setiap kategori ke dalam matriks e. Hasilnya dapat di lihat yang memiliki nilai keanggotaan paling besar berada pada kategori apa, itulah hasil evaluasi dengan menggunakan metode fuzzy synthetic evaluation.

Berdasarkan perbandingan matriks W dan $\mathrm{R}(\mathrm{W} \circ \mathrm{R})$ yang telah dilakukan di atas, diperoleh hasil seperti yang ditunjukkan pada tabel 4 di bawah ini: 
Tabel 4 Tabel Hasil Penilaian terhadap Alternatif Pemilihan Vendor

\begin{tabular}{cccccccc}
\hline No & Vendor & SBR & BR & C & BK & SBK \\
\hline 1 & AGM & 0,00 & 0,074 & 0,22 & 0,20 & 0,19 \\
2 & ADR & 0,00 & 0,039 & 0,21 & 0,22 & 0,053 \\
3 & BBC & 0,00 & 0,043 & 0,22 & 0,207 & 0,059 \\
4 & BMJ & 0,00 & 0,045 & 0,22 & 0,20 & 0 \\
5 & MNJ & 0,00 & 0,045 & 0,21 & 0,22 & 0,027 \\
6 & NSM & 0,00 & 0,044 & 0,22 & 0,207 & 0,027 \\
7 & PRX & 0,00 & 0,061 & 0,22 & 0,21 & 0,125 \\
8 & SDT & 0,00 & 0,044 & 0,22 & 0,21 & 0 \\
\hline
\end{tabular}

Perusahaan menetapkan akan memilih 2(dua) vendor yang memiliki kinerja paling baik, di mana dapat dilihat dari hasil tabel di atas maka vendor Adi Sarana Armada dan Muna Jaya Express memiliki nilai keanggotaan paling besar dibanding dengan vendor yang lainnya yaitu sebesar 0,22 dengan kategori vendor "baik".

\section{Pengalokasian Order}

Dengan menggunakan kedua 3PL sebagai resource dalam melakukan pengiriman serta penyelesaian diselesaikan menggunakan Solver Excel, maka output dari alokasi order diilustrasikan pada Tabel 5

Keterangan:

$\begin{array}{ll}\mathrm{A} & =\text { PT Adi Sarana Armada } \\ \mathrm{B} & =\text { Muna Jaya Expres } \\ \text { Produk 1 } & =\text { Alpenliebe } \\ \text { Produk 2 } & =\text { HD White Blister } \\ \text { Produk 3 } & =\text { Mentos }\end{array}$

dimana total biaya optimal yang diperoleh untuk seleruh kiriman adalah Rp 8.467.347.

\section{ANALISIS DAN PEMBAHASAN}

Metode Fuzzy synthetic evaluation ini dapat mengakomodir variabel-variabel yang sifatnya linguistic. Metode Fuzzy synthetic evaluation adalah suatu proses pengambilan keputusan dengan cara mengevaluasi alternatif atau mitra kerjanya dalam rangka mencapai tujuan yang berlandaskan pada kriteria dan subkriteria yang didasarkan pada permasalahan yang dihadapi oleh perusahaan. Fuzzy synthetic evaluation berguna untuk mempermudah dalam melakukan penilaian evaluasi kinerja vendor pada perusahaan, yang nantinya diharapkan akan mendapatkan hasil yang maksimal baik bagi pihak perusahaan khususnya maupun bagi vendor yang merupakan bagian dari perusahaan sendiri. Oleh karena itu, dalam pembahasan ini dilakukan analisis penilaian terhadap vendor untuk menangani distribusi account PVMI berdasarkan hasil pengolahan data. Berdasarkan penilaian yang telah dilakukan di atas terhadap penilaian Alternatif, maka dapat diketahui bahwa setiap vendor mempunyai nilai alternatif yang berbedabeda terhadap nilai keanggotaannya. Namun apabila diurutkan per kategori, untuk PT Adi Sarana Armada (ADR), Berkat Bahada Cargo (BBC) dan Muna Jaya Expres (MNJ) memiliki kualitas kinerja yang baik (BK), kemudian untuk Arti Guna Mandiri (AGM), PT Bamanja (BMJ), Nasa Mustika Transport (NSM), Prima Sarana Ekspress (PRX) dan PT Sumber Dwi Tunggal (SDT) memiliki kinerja yang cukup (C).

Pengalokasian Order yang diterapkan penulis dapat memberikan alternatif penentuan alokasi yang dapat dilakukan dengan mudah karena dapat memanfaatkan solverexcel yang mana sangat mudah dijumpai dalam penggunakaan komputer di perushaan, karena pada umumnya aplikasi Ms. Office merupakan aplikasi dasar yang pasti dimiliki perusahaan dalam menjalankan proses bisnisnya.

Diperoleh biaya distribusi minimum perhitungan dengan metode VAM pengujian MODI serta penyelesaian dengan solver excel sebesar Rp8.467.347. PT Adi Sarana Armada terpilih sebagai vendor prioritas untuk wilayah kiriman Banten, Lampung, dan Tanggerang, sementara Muna Jaya Express terpilih sebagai vendor prioritasuntuk wilayah kiriman Surabaya, Malang, dan Jember. Prioritas ini ditentukan dari harga kiriman yang diberikan oleh masing-masing vendor ke tiap-tiap tujuan kiriman.

\section{KESIMPULAN}

Penentuan vendor prioritas dilakukan dengan menggunakan metode Fuzzy Synthetic Evaluation yang didasarkan pada 5 (lima) kriteria yaitu harga/tarif, network coverage, office equipment (EDI link, Email capability, Internet banking), infratruktur 
(Global Positioning System dan Waybill Tracing) dan kualitas pelayanan, dimana terdapat sub kriteria untuk kualitas yang terdiri dari kualitas alat angkut beserta umur peralatan, asuransi, dan ability to provide Custome Delivery. Dua vendor prioritas terpilih yaitu PT Adi Sarana Armada dan Muna Jaya Expres sama-sama memiliki nilai keanggotaan terbesar yaitu 0,22 di kategori "baik" yang berarti bahwa kedua vendor tersebut memiliki kinerja yang lebih baik dibandingkan dengan vendor trucking lainnya.

Alokasi order yang dilakukan dengan metode VAM dan pengujian MODI serta dibantu penyelesaiannya dengan aplikasi solver excel memberikan biaya distribusi yang telah optima dengan total biaya Rp8.467.347. Selain itu, PT Adi Sarana Armada terpilih sebagai vendor prioritas untuk wilayah kiriman Banten, Lampung, dan Tanggerang, sementara Muna Jaya Express terpilih sebagai vendor prioritas untuk wilayah kiriman Surabaya, Malang, dan Jember. Prioritas ini ditentukan dari harga kiriman yang diberikan oleh masingmasing vendor ke tiap-tiap tujuan kiriman.

\section{DAFTAR PUSTAKA}

1. Dimyati, Tjutju Tarliah.2004.Operations Research.Bandung: Sinar Baru Algesindo

2. Kusumadewi, Sri.2004.Aplikasi Logika Fuzzy untuk Pendukung Keputusan. Yogyakarta: Graha Ilmu

3. Siswanto. 2007.Operation Research. Jakarta : Erlangga

4. Susatio, Yerri.2006.Matchad: Solusi Problematika Matematika dan Fisika.Yogyakarta: Andi Offset
5. Taha, Hamdy A.2007.Riset Operasi.Jakarta: Erlangga

6. Agustian, Dede.2011. Evaluasi Kinerja Supplier Kain Cotton Combed 20s di PT Progressio Indonesia

7. Marsita, Emay, 2009. Evaluasi Kinerja Supplier Kain Untuk Jenis Kain PE 40s DK Dengan Menggunakan Metode Fuzzy Synthetic Evaluation.

8. Ulfa, Rizki Meiza.2011. Analisis Kinerja Vendor Untuk Mendapatkan Vendor Prioritas Dalam Menangani Container Kosong Di Pt American President Line Indonesia Dengan Metode Fuzzy Synthetic Evaluation

9. Widawati, Ika.2011. Analisis Pemilihan Shipping Line untuk Account Jc. Penney dengan Tujuan U.S.A di PT. Damco Indonesia dengan Menggunakan Metode Analytical Hierarchy Process (AHP)

10.Athaullah, Ahmad.2011.Implementasi Metode Vogel untuk Optimalisasi Distribusi Berorientasi Objek

11.Puspitorini, Pipit Sari.2011. Model Pemilihan Dan Alokasi Order $\mathrm{Ke}$ Perusahaan Jasa Logistik .

12.Supriyanto, Hari.2010.Pendekatan Fuzzy Quality Function Deployment dalam Pemilihan Supplier

13. (_ http://www.mediaindonesia.com/ Industri-Logistik-Diperkirakan-Tumbuh83-Persen , diakses pada 30 mei 2012)

14.(http://www.frost.com/prod/servlet/, diakses pada 1 Juli 2012)

15.(http://hardipurba.com/2008/10/30/delapa n-dimensi-kualitas-david-garvin.html, diakses pada 12 Juli 2012)

16.(http://id.wikipedia.org/wiki/harga, diakses pada 12 Juli 2012) 
Tabel 5 Hasil Alokasi Order Berdasarkan Volume (cdm) dengan Solver Excel

\begin{tabular}{|c|c|c|c|c|c|c|c|c|c|c|c|c|c|c|c|c|c|c|c|c|c|}
\hline \multirow{3}{*}{ Supplier } & \multicolumn{18}{|c|}{ Tujuan } & \multirow{2}{*}{\multicolumn{3}{|c|}{ Kapasitas }} \\
\hline & \multicolumn{3}{|c|}{ Bekasi } & \multicolumn{3}{|c|}{ Lampung } & \multicolumn{3}{|c|}{ Malang } & \multicolumn{3}{|c|}{ Surabaya } & \multicolumn{3}{|c|}{ Tanggerang } & \multicolumn{3}{|c|}{ Jember } & & & \\
\hline & $\begin{array}{c}\text { Produk } \\
1\end{array}$ & \begin{tabular}{|c} 
Produk \\
$\mathbf{2}$
\end{tabular} & $\begin{array}{c}\text { Produk } \\
\quad 3\end{array}$ & $\begin{array}{c}\text { Produk } \\
1\end{array}$ & \begin{tabular}{|c} 
Produk \\
2
\end{tabular} & $\begin{array}{c}\text { Produk } \\
\mathbf{3}\end{array}$ & $\begin{array}{c}\text { Produk } \\
1\end{array}$ & $\begin{array}{c}\text { Produk } \\
2\end{array}$ & \begin{tabular}{|c} 
Produk \\
$\mathbf{3}$
\end{tabular} & $\begin{array}{c}\text { Produk } \\
1\end{array}$ & \begin{tabular}{|c} 
Produk \\
2
\end{tabular} & \begin{tabular}{|c|c} 
Produk \\
$\mathbf{3}$
\end{tabular} & $\begin{array}{c}\text { Produk } \\
1\end{array}$ & $\begin{array}{c}\text { Produk } \\
2\end{array}$ & $\begin{array}{c}\text { Produk } \\
\mathbf{3}\end{array}$ & $\begin{array}{c}\text { Produk } \\
1\end{array}$ & $\begin{array}{c}\text { Produk } \\
2\end{array}$ & $\begin{array}{c}\text { Produk } \\
3\end{array}$ & Digunakan & Tersedia & Sisa \\
\hline A & 8482,2 & 11015,3 & 11787,9 & 10052,3 & $\mid 11043,2$ & 10035,9 & o & $\mathbf{0}$ & $\mathbf{0}$ & $\mathbf{0}$ & $\mathbf{0}$ & $\mathbf{0}$ & 6504,4 & 7546,9 & 6531,8 & $\mathbf{0}$ & $\mathbf{0}$ & $\mathbf{0}$ & 83000 & 83000 & $\mathbf{0}$ \\
\hline B & 0 & 3724,26 & 0 & 0 & $\mathbf{0}$ & $\mathbf{0}$ & 7850,2 & 9965 & 5613,3 & 8543,4 & 11582,2 & 4473,6 & 0 & 0 & 0 & 7177,3 & 4327,9 & 4558,7 & 67815,86 & 73800,00 & 5984,14 \\
\hline
\end{tabular}

